九州大学学術情報リポジトリ

Kyushu University Institutional Repository

\title{
Water Demand Prediction Model Used for General PUrpose : Referring to the Thailand Gravity Irrigation District (5)
}

Fukuda, Tetsuro

Faculty of Agriculture, Gradute School, Kyushu University

https://doi.org/10.5109/4699

出版情報：九州大学大学院農学研究院紀要. 50 (2)，pp.909-916，2005-10-01. Faculty of Agriculture, Kyushu University バージョン：

権利関係 : 


\title{
Water Demand Prediction Model Used for General Purpose -Referring to the Thailand Gravity Irrigation District (5)-
}

\author{
Tetsuro FUKUDA* \\ Laboratory of Irrigation and Water Utilization, Division of Regional Environment Science, \\ Department of Bioproduction Environmental Sciences, Faculty of Agriculture, \\ Graduate School, Kyushu University, Fukuoka 812-8581, Japan \\ (Received July 20, 2005 and accepted July 26, 2005)
}

I tried the development of general-purpose model of water demand forecasting been applicable in what kind of district. This model contained estimation of the planting pattern, calculation of irrigation water requirement, estimation of reuse water, etc., and it was able to be confirmed that these were models with the high reliability.

\section{INTRODUCTION}

A water demand estimation model in the gravity irrigation district was developed in the previous report. In this paper, the model is improved, and the development of the applicable general-purpose model is also tried in other district. The district chosen in the object of the model verification is Chainat Pasak district which is located in the left bank of Chao Phraya River, and in a little upstream of the Sam Chuk district.

\section{OUTLINE OF TARGET AREA}

Chainat Pasak Canal irrigates the left bank area, about 120000ha (about 770000Rai), of Chao Phraya River by taking necessary water from Chainat Dam. Fig. 1 gives the water supply system in the Chao Phraya delta. Chainat Pasak Canal is located in the right upper part in Fig. 1. The command area is partitioned into four projects, Manorom Project, Chang Kae Project, Koke Kathiem Project and Reong Rang Project, is operated and maintained by each Project.

The main canal has around 30 lateral canals. Four lateral canals were chosen from the especially big lateral canals in the canal. They are 9R, 16R, 21R and 24R. Then, the following were tried on each branch canal : Analysis of the water allocation management actual condition and application of the water demand prediction program.

\section{FORMULATION OF PLANTING PATTERN}

Though the cropping investigation was carried out in this region, the result was poor, and it was hard to be used as a practical use. In the meantime, it was proven to be the data which it can sufficiently trust, though observation data of water level and gate opening in each regulator needed a little correction. Then, the flow discharge passing

\footnotetext{
* Corresponding author (E-mail: tfukuda@bpes.kyushu-u.ac.jp)
} 


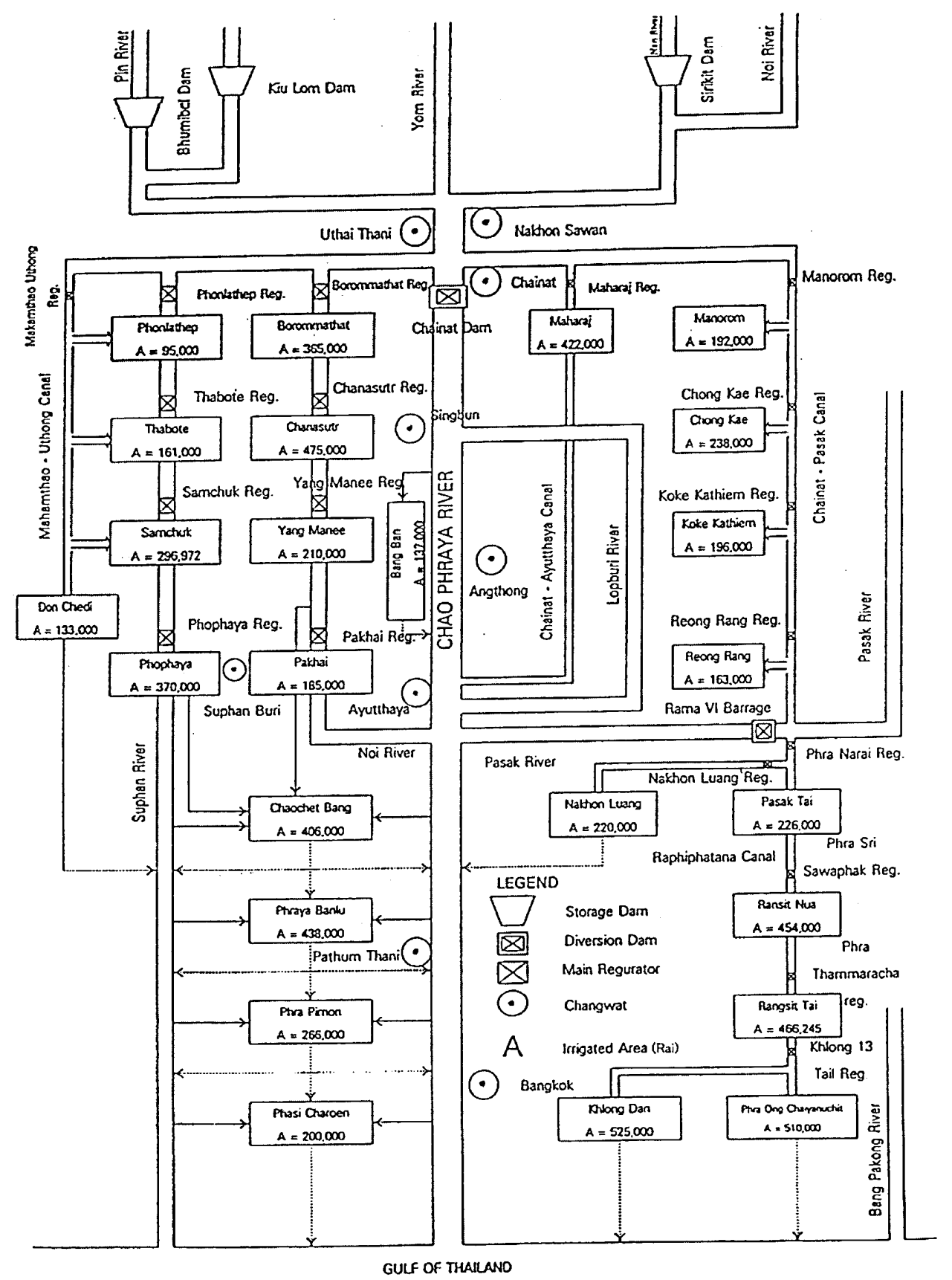

Fig. 1. Water supply system in Chao Phraya delta 
each regulator was calculated from observation data of the regulator, and planting pattern of this region should be deduced from this water supply results. Estimation method of planting pattern is shown in the following.

\section{Hypothetical condition for simulation}

- The crop except for the paddy rice is supposed to exist for $10 \%$ of command area, and consumptive water use is calculated as the fruit tree has been planted throughout one year

- $90 \%$ of command area is rice paddy in the rainy season.

- Planting pattern is trapezoidal approximately as shown in Fig. 2.

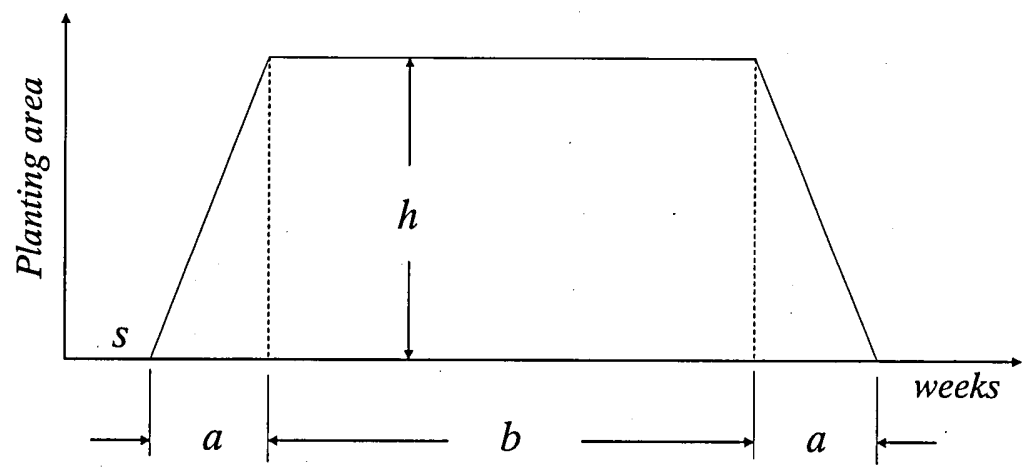

Fig. 2. Planting pattern

$s$ : Planting commencing time (unit: weeks)

$a:$ Increase or decrease period (unit : weeks)

$b:$ Peak duration (unit: weeks)

$h:$ Planting area (unit : rai)

\section{Preparation of planting pattern}

Planting pattern is decided according to following procedure.

- Water supply commencing time and stop time from the water supply results are decided.

- Irrigation period of the rice paddy with standard is for 13 weeks, and the irrigation area is calculated with the inverse proportion to actual irrigation period (length of $a+b$ ).

- Concretely, trapezoidal height, namely, planting area $h$ is calculated using the following formula, if planting possible area of the paddy rice is $A$.

$$
h=\frac{A \times 13}{(a+b)}
$$

- In the rainy season if there are two planting patterns, each planting area is divided based on the ratio of a value of " $h \cdot(a+b)$ ". Planting area " $h$ " in the dry 
season can be decided in proportion to water supply volume in the rainy season.

- Planting area in the dry season $h$ is calculated from the ratio of water supply in rainy season and water supply in the dry season on the basis of the value in the rainy season.

Table 1 and Fig. 3 give an example of the planting pattern made by the above procedure.

Water demand prediction program shown in Fig. 4 is used in order to calculate planting area of the every crop on the basis of Table 1 data. You should prepare the file which picked out only the data of the necessary regulator from Table 1 , if you want to calculate this for each regulator. Table 2 shows the example of the text file of the $9 \mathrm{R}$ regulator.
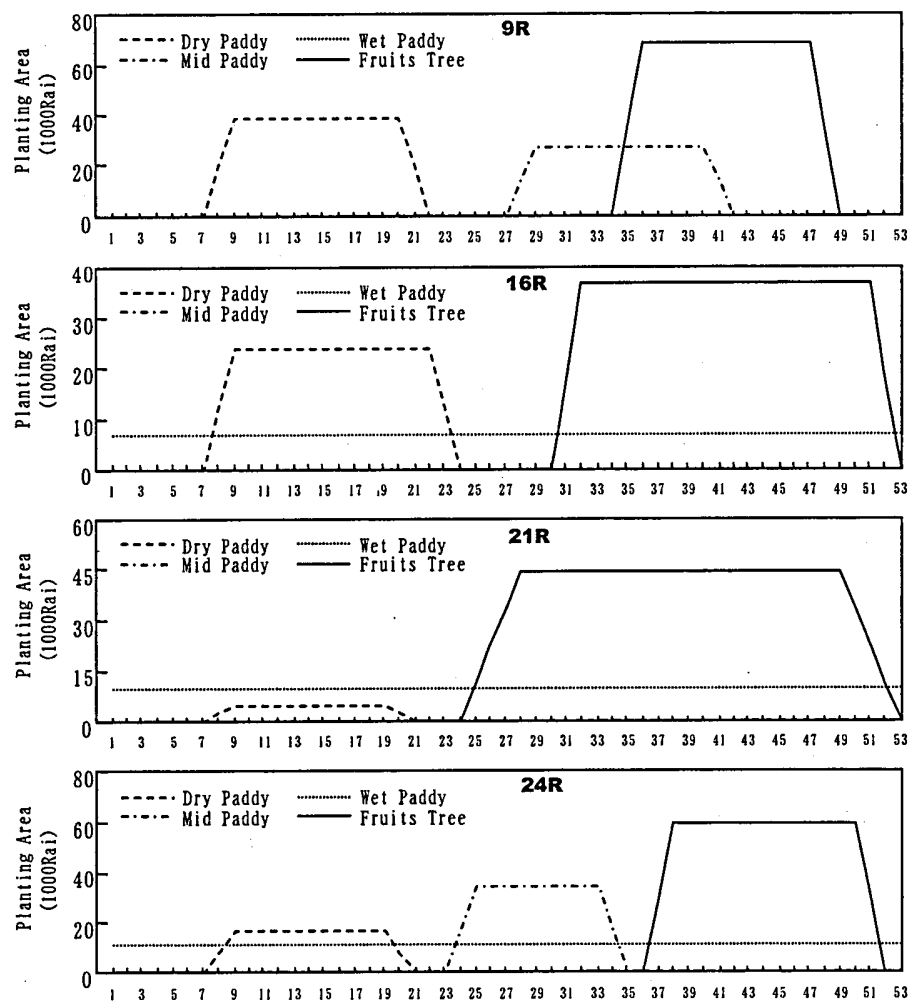

Fig. 3. Planting Pattern in Chainat Pasak Canal Area (1990)

When planting area of the every crop is calculated, regulator name and planting pattern parameter file name are designated in the operation panel of water demand prediction model of Fig. 4. The output file name is designated, if it is necessary. It is made in the adequate name, if it is not designated. It is executed by clicking "Planting Pattern" button of the upper right of this panel. 


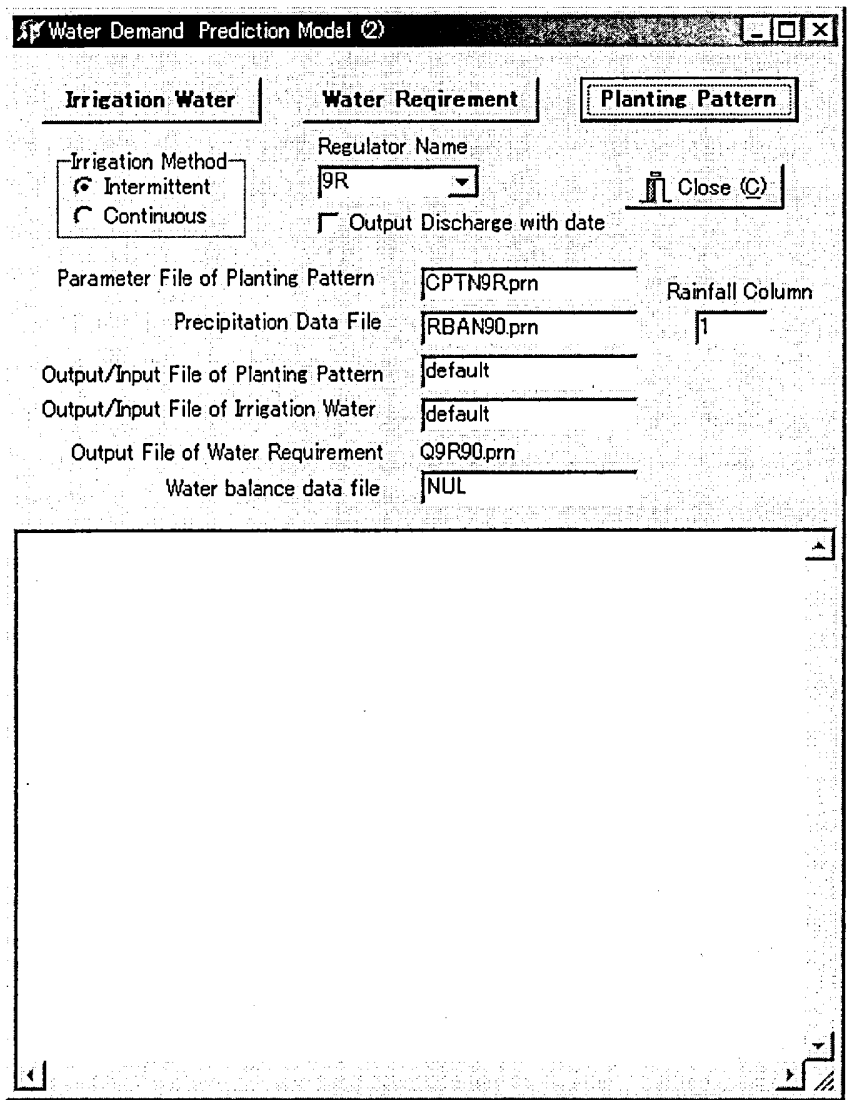

Fig. 4. Operation panel of water demand estimation model

Table 1. Planting Pattern (Chainat Pasak Canal Area)

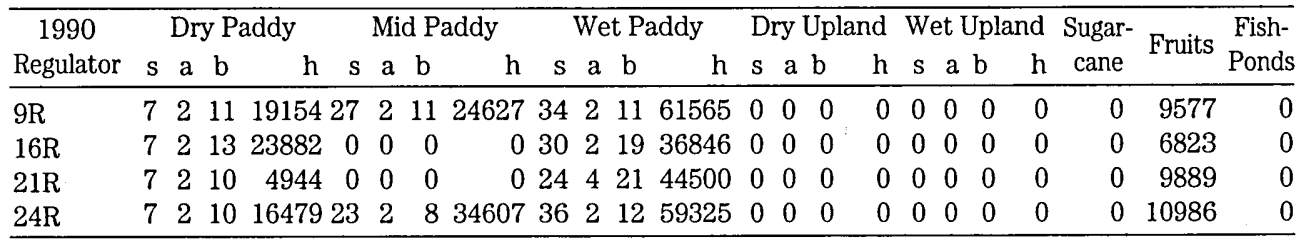

Table 2. Example of Planting Pattern (9R Regulator, File Name: 'CPTN9R.prn')

\begin{tabular}{|c|c|c|c|c|c|c|c|c|}
\hline 1990 & & Dry Paddy & Mid Paddy & Wet Paddy & Dry Upland & Wet Upland & Sugar- & Fish- \\
\hline Regulator & $\mathrm{s}$ & $a b \quad h$ & $\begin{array}{llll}\mathrm{s} & \mathrm{a} & \mathrm{b} & \mathrm{h}\end{array}$ & $\begin{array}{llll}s & a & b & h\end{array}$ & $\mathrm{~s} a \mathrm{~b} \quad \mathrm{~h}$ & $\mathrm{~s} a \mathrm{~b} \quad \mathrm{~h}$ & cane & Fruits Ponds \\
\hline $9 \mathrm{R}$ & 7 & $11 \quad 1915427$ & 1124627 & $\begin{array}{llll}34 & 2 & 11 & 61565\end{array}$ & 00 & 00 & 0 & 9577 \\
\hline
\end{tabular}




\section{CALCULATION OF IRRIGATION WATER REQUIREMENT}

Crop coefficient (Pan coefficient) clarified in the previous report (T. Fukuda, 2005) was decided on the assumption of full face irrigation, and the estimate of the evapotranspiration is considerably calculated from the actual condition in the big texture. According to survey on actual situation of the irrigation which the author carried out in Japan, Pan coefficient in open field was about 0.3. Pan coefficient was improved referring to this result and survey on actual situation of the irrigation in Thailand. Table 3 shows this improved value.

The calculation of irrigation water requirement clicks the "Irrigation Water" button of the upper left of the operation panel of above-mentioned Fig. 4, after rainfall data files are designated. The selection of the irrigation method is possible, if it is necessary, and or, it is possible to designate the output file.

Table 3. Modified Pan Coefficient

\begin{tabular}{lcc}
\hline Kind of Crops & Pan Coefficient & Modified Pan Coefficient \\
\hline Upland Crops & 0.8 & 0.3 \\
Sugarcane & 0.9 & 0.2 \\
Fruits & 1 & 0.1 \\
\hline
\end{tabular}

\section{PREDICTION OF WATER REQUIREMENT}

The water demand prediction model is used for the calculation of the water requirement. Calculating area prior to the execution, namely Regulator Name, is chosen. And, it is necessary to designate the file of irrigation water requirement already calculated. The output file is output of the file adequately named, if it is omitted. The execution of the calculation may click the "Water Requirement" button of the upper center of the operation panel of Fig. 4. It is possible that the output file is graphed by reading in spread sheet software such as Excel.

The reused water ratio (proportion within percolation of water recycled as irrigation water) will be assumed in the program as following.

In the dry season (November to June) : 1.0.

In the rainy season (July to October) : 0.5 .

Fig. 5 gives the example of the relation between actual water supply and simulated water demand. A good relationship between these values was obtained according to this result.

\section{CONCLUSION}

Following fact was confirmed, because there was the considerably good coincidence in the comparison of simulation value and water supply results.

1. The validity of the planting pattern estimation method.

2. The validity of the estimate of consumptive water use of each crop. 
3. The validity of the estimate of return flow ratio.

4. The validity of the simulation.

Like this, it was able to be confirmed that there was considerably the generality on water demand estimation method which the author developed in the Thailand gravity irrigation district.
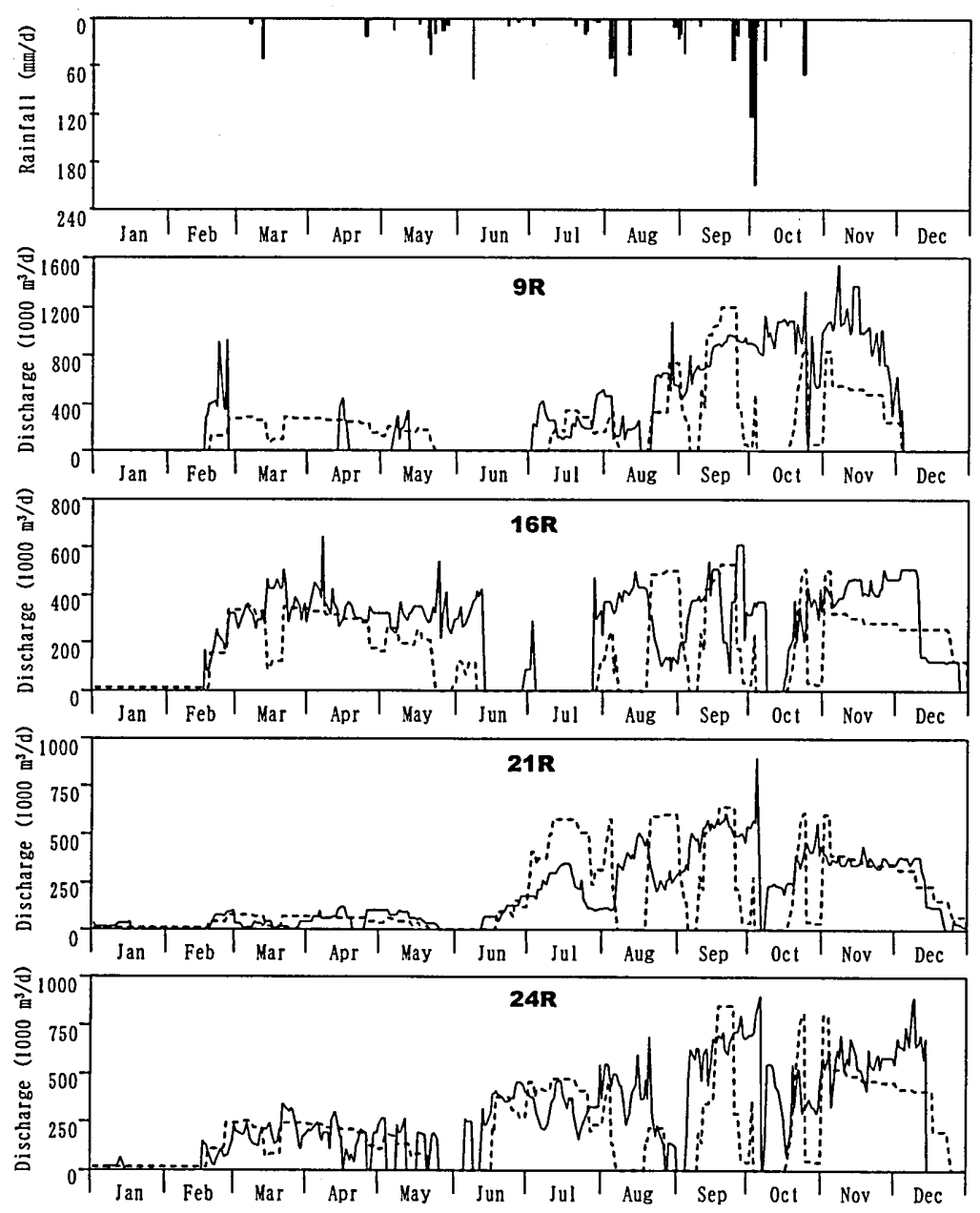

Fig. 5. Actual water supply and simulated water demand (Chainat Pasak Canal, 1990) (Solid line : Actual water supply, Broken line : Simulated water demand) 


\section{REFERENCES}

Royal Irrigation Department 1990 Crop Coefficient and Pan Coefficient (Thailand)

Testuro Fukuda 2005 Estimation model of water requirement in farmand-Referring to the Thailand gravity irrigation district (1)-, J. Fac. Agr., Kyushu Univ., 50(2) (in press)

Testuro Fukuda 2005 Actual water consumption and water management in paddy field-Referring to the Thailand gravity irrigation district (2)-, J. Fac. Agr., Kyushu Univ., 50(2) (in press)

Testuro Fukuda 2005 Estimation of water requirement for each area and actual water allocation-Referring to the Thailand gravity irrigation district (3)-, J. Fac. Agr., Kyushu Univ., $\mathbf{5 0}(2)$ (in press)

Testuro Fukuda 2005 Construction of water demand prediction model-Referring to the Thailand gravity irrigation district (4)-, J. Fac. Agr., Kyushu Univ., 50(2) (in press) 